American Journal of Applied Sciences 5 (9): 1149-1157, 2008

ISSN 1546-9239

(C) 2008 Science Publications

\title{
Political Stability and Balance of Payment: An Empirical Study in Asia
}

\author{
Arfan Ali, Tan Shukui, Santhirasegaram Selvarathnam, Xu Xiaolin and Abdul Saboor \\ Huazhong University of Science and Technology (HUST) 430074, \\ Wuhan, People's Republic of China
}

\begin{abstract}
This study analyze that influences of political stability on balance of payment and relative importance of political stability and economic freedom for healthy of balance of payment and exchange rate stability. Political stability has an important role in determination of healthy of balance of payment than economic freedom. This study focus on selected 10 Asian countries of various income levels and test the factor of political stability and economic freedom in stability of balance of payment by using a simple econometric model with various techniques. Our empirical finding shows that political stability is more important than economic freedom in stabilizing balance of payment. Stable political regime with visionary leadership leads the nations to higher level of favorable balance of payment. Political stability is playing major role than theoretical explanation to achieve surplus of balance of payment hence exchange rare stability. Surplus of trade balance, foreign direct investment and higher international reserves hence appreciation of Yuan in china mostly depends on its long term political stability under one party political system rather than pure theoretical determination of balance of payment. Attaining of political stability before economic freedom is policy implication of this study to achieve international financial stability.
\end{abstract}

Key words: Political stability, balance of payment, economic freedom, exchange rate, international reserves, foreign direct investment

\section{INTRODUCTION}

There are so many models at stabilization policy in open economy, in international macroeconomic literatures. They have paid a pure theoretical attention on determinant of stability of balance of payment such as Current account balance and capital account balance. Foreign direct investment (FDI) is playing a major role in stability of balance of payment in globalization world for last three decades. Global imbalances of balance of payment among the economies can be explained by the differences in the degree of political stability in their history of economic development.

Economic financial imbalances among countries can be explained by the differences in the degree of political stability in the countries ${ }^{[9]}$. Political stability and reforms played a vital role in economic growth and development in China ${ }^{[7,11]}$. Even in the presence of the economic barriers, the developing countries can overcome their balance of payment problems if they have a stable political regime with visionary leadership. International finance which is based on long run sustainable growth is not a short term process. It is a long term process that should be managed with foresight and vision. Political stability provides a solid base for long run economic growth and financial strength as it was seen in Singapore ${ }^{[2,3,4,14]}$. The thinking on balance of payment stability has paid more attention on stability of political regime by authoritarian regime in development strategy ${ }^{[6]}$. Despite the global economic barriers, developing countries can overcome their economic problems if they have a stable political regime with good leadership.

There exists, at least, at the level of abstraction, a close relationship between political stability and theoretical determinants of balance of payment. Export, foreign transfers, tourist earnings international aids and foreign direct investment have a close link with the stability of the political regimes. Mobilization of international financial resources can only be undertaken effectively by a stable government. A stable government will be in a position to invest a large amount of capital on human resource development which can be financed by international aids.

Corresponding Author: Arfan Ali, Huazhong University of Science and Technology (HUST) 430074, Wuhan, People's Republic of China 
It is said, developing countries do not have enough capital to invest on human development, research, economic and social infrastructure development, which are key determinants of economic growth. The return from investment in these sectors is realized after a long period of time. In most developing countries governments do not have funds to invest in these sectors. It has to come from foreign investors. Stable governments under leaders with vision has greater opportunity to win foreign investor's confidence and countries with such governments attract direct and portfolio investments. Reform and opening up increase foreign direct investment with technology. Marketfriendly approach highlights the importance of political stability. The stable political environment overcomes those problems which encourage inflows of international payment. Political stability is thus no more a theoretical determinant of stability of international finance. Asian success stories have proved political stability as a practical determinant of healthy of balance of payment ${ }^{[13]}$.

In the 1960's confiscation, expropriation and nationalization became critical concerns for companies with foreign operations. These increased concerns about political risk were treated in economic literature mostly in the conceptual framework of the relations between host countries and multinational enterprises. The field of political risk and instability research became more complex after the 1979 fall of the Shah of Iran, as questions of political stability were added to the variables being examined, that is to confiscation, nationalization and expropriation.

The extension or enlargement of the political risk scope to political instability was followed by initial attempts in economic literature to quantify and clarify the concept of political stability defined as a mechanism for the objective evaluation of foreign investment climates. In addition, this enlargement of the political risk scope gave birth to a variety of economic studies related to the methods or approaches used to assess scientifically the political risk. Among these studies, it is worth mentioning the paper of Rummel and Heenan ${ }^{[12]}$, which was one of the first studies dealing with the assessment of political instability and proposing a method of converting polemical instability into probabilistic terms thus providing a scientific definition of political risk.

Accordingly, there exists in the economic literature different ways of defining political risk ${ }^{[1]}$. Indeed the definition of political risk depends on the perspective in which ones views of micro level. The restrictive definition of political risk in contrast to the extensive definition encompasses only political instability that is political risk that is originated exclusively in the state activities. Furthermore, only unpredictable political events are accounted in this perspective for political risk. Both the extensive and restrictive political risk definition is descriptive and non-economic sense.

Even though some countries in Africa and Asia have an attractive economic incentive packages to foreign investors by allowing more economic freedom, they could not receive a considerable FDI and other financial assistances from rest of world because of the political instability. On the other hand some countries such as china, Malaysia with a limited incentives with less economic freedom are getting more foreign financial resources from rest of world, because of stable political regimes. Export oriented industrialization, attracting the tourists, getting private and government transfer payment, FDI, Selling of long run government bonds to foreigners and other form of capital inflows mostly depend on political stability than economic factors.

Theoretically, interest rate is one of more important factor in determination of investment, but most cases of political risk economies, it does not play such as a role in determination of investment ${ }^{[19]}$. Stability of balance of payment is a long run process. Political uncertainty, no doubt, is an investor's nightmare. It does disturb the flow of foreign direct investment plans both into the private sector as well as the government owned public sector units and that surely affects economic growth. It is asserted by economists that political stability induces the higher private investment and as well as economic growth. It is said, developing countries do not have enough capital to invest on human development, research, economic and social infrastructures which are key factors for economic growth. The payoff of investment in these sectors comes after long times from invested period and the investors have to wait for a long period to enjoy the returns of their investment If government does not have enough capital to invest in those sectors, the local investors or foreign investors (government or private) are investing capital in these sectors through the various forms of investment But problem is, who is guarantor for this heavy capital.

Present government can give some assurance but no one knows what will happen in future. Here we can assert our argument very strongly. If one government, whether democracy or non democracy has a stable regime power with a good visionary leadership, it can win the confidence of investors for investing. Such stability increases the capital not only in the form of direct investment but also portfolio investments such as 
investments on long run government bonds and stock markets etc. It provides capital for both government and private sectors which accelerates economic growth with stability of balance of payment.

Asian successors such as Singapore, South Korea, Taiwan and Hong Kong have won their growth with healthy balance of payment by increasing capital on theoretical determinant of economic growth by maintaining a stable regime ${ }^{[15,17]}$. Instead, political instability in Indonesia in 1997 was one of the causes for Asian financial crises ${ }^{[18]}$. Reforms and opening increase the foreign direct investment with technology. A country, which has political instability, is facing lack of foreign capital hence balance of payment problems.

\section{MATERIALS AND METHODS}

Referring many methods, this study form an index for political stability during 1990-2005 based on previous study in political stability and economic growth. The index for political stability is obtained from previous study $^{[10]}$. Index for political stability covers nine variables, which are longevity of the regime, Election density ratio, Increase in the number of political parties, Strength of ruling party, Military expenditure as a percentage of GDP, Index of democratization, Composite of ICRG risk rating, Numbers of persons internally displaced and Increment of political parities in national assembly.

Our purpose is to asses the variables related with balance of payment through this index. The data on balance of payment is taken from world development report $^{[10]}$. Table in appendix illustrates our sample of countries and variables. International Reserves (IR), Percentage depreciation Against US\$ during 199505(EXD), Foreign Direct Investment in 1997 and 2003 billion US\$ (FDI), Current Account Balances billion US\$ in Changes between 1997-2005 (CUACB), Index for political stability $\left(\mathrm{X}_{1}\right)$ is average for period 19902005 and Index for economic freedom $\left(X_{2}\right)$ for 2003.

Gross international reserves and exchange rate stability are indicators of nature of overall balance of payment. So, first, this study pays attention to International reserve and exchange rate. A dependent variable international reserve is determined mainly by political stability. With other economic variables, we can define following function.

$$
\mathrm{IR}=\mathrm{f}\left(\mathrm{X}_{1}, \mathrm{X}_{2}\right)
$$

Where:

IR = Value of International reserves

$\mathrm{X}_{1}=$ Socio-Political factors (All factors measured by index for political stability)

$\mathrm{X}_{2}=$ Economic factors. (All factors measured by index for economic freedom ${ }^{[5]}$

The factors determine the economic freedom can be assumed and taken as economic factors determine the stability of balance of payments. Index for economic freedom includes more than 50 variables which fall in following 10 categories or factors, of economic freedom such as trade policy, fiscal burden of government, government intervention in the economy, monetary policy, capital flows and foreign investment, banking and insurance, wages and prices, property rights, regulations and black market activities.

$$
\mathrm{EXD}=\mathrm{C}+\mathrm{B}_{1} \mathrm{X}_{1}+\mathrm{B}_{2} \mathrm{X}_{2}+\mathrm{u}
$$

Where:

EXD $=$ Percentage of depreciation of currency against US\$ during 1995-2005 ( $\left.\mathrm{Y}_{1}\right)$

$\mathrm{X}_{1}=$ Index for political stability for 1990-2005

$\mathrm{X}_{2}=$ Index for economic freedom for 2003

\begin{tabular}{|c|c|c|c|c|c|c|c|c|}
\hline \multirow[b]{2}{*}{ Countries } & \multirow[b]{2}{*}{ IR } & \multirow[b]{2}{*}{ EXD } & \multicolumn{2}{|l|}{ FDI } & \multicolumn{2}{|c|}{ CUACB } & \multirow{2}{*}{$\begin{array}{l}X_{1} \\
1990-05\end{array}$} & \multirow{2}{*}{$\begin{array}{l}X_{2} \\
2003\end{array}$} \\
\hline & & & 1997 & 2003 & 1997 & 2005 & & \\
\hline Singapore (1990-05) & 123.5 & 20.28 & 8.69 & 9 & 25.24 & 10.3 & 87.65 & 1.56 \\
\hline India (1990-05) & 145 & 41.34 & 3.35 & 5 & -13.19 & -7.9 & 0.21 & 3.49 \\
\hline Malaysia (1990-05) & 78.9 & 56.37 & 5.11 & 2 & 15.35 & 20.1 & 72.38 & 2.98 \\
\hline SriLanka (1990-05) & 2.38 & 92.19 & 0.43 & 0.229 & -0.38 & -0.01 & 9.45 & 3.19 \\
\hline Thailand (1990-05) & 51.9 & 81.99 & 3.74 & 2 & -5.9 & -2.1 & 42.95 & 2.99 \\
\hline S. Korea (1990-05) & 210.4 & 35.62 & 2.84 & 4 & 14.34 & 23.1 & 40.34 & 2.63 \\
\hline Philippines (1990-05 & 18.09 & 138.7 & 1.22 & 0.347 & 3.87 & 8.1 & 2.06 & 3.23 \\
\hline China (1990-05) & 795.1 & 0.001 & 44.2 & 54 & 129.1 & 99.4 & 100 & 3.4 \\
\hline Pakistan (1990-05) & 11.79 & 93.64 & 0.71 & 1 & -1.43 & 2.2 & 12.17 & 3.33 \\
\hline Nepal (1990-05) & - & 44.81 & 0.023 & 0.015 & -0.46 & -0.36 & 29.35 & 3.53 \\
\hline
\end{tabular}

Appendix: Independent variables of balance of payment

Source: World development reports 2006, Heritage Foundation, 2006 and Muhammad 2008 
Over the past three decades, foreign direct Investment has been the major component of capital flows since firms domiciled in one country have established foreign branches and purchased foreign firms. Indeed Foreign direct investment has become the prime engine to foster growth and employment in the industrialized countries, to facilitate the development of less developed countries (LDCs) and the restructuring and internationalization of formerly socialist or sheltered areas. It is therefore not surprising that a global race for foreign direct investment is taking place worldwide.

A foreign direct investment implies a permanent relationship between the investor and the object and particularly the opportunity for real influence over the object's operations. Investments which do not fit this definition are to be classified as portfolio investments. Undoubtedly, foreign investors in developing countries face many kinds of political risks partly due to the lack of political stability and of political capability of these countries. That FDI in LDCs is confronted with political risks is by the fact shown that most international investment rules, as well as public and international political risk-insurance, deals mostly with political environment in LDCs.

Indeed, most political risk indicators are exclusively conceived for LDCs. Given the common emphasis on political risk in LDCs, it is tempting to conclude that such political risks do not exist in industrial nations. Such a conclusion is however very misleading for it does not take into consideration the various restrictive policy measures in industrialized countries which represented a political risk in real sense of this term for FDI. What factor relative importance to determine FDI? I take the FDI in middle year (1997) of research period.

$$
\mathrm{FDI}=\mathrm{C}+\mathrm{B}_{1} \mathrm{X}_{1}+\mathrm{B}_{2} \mathrm{X}_{2}+\mathrm{u}
$$

Where:

FDI $=$ Value of net FDI in middle year of study

$\mathrm{X}_{1}=$ Index for political stability for 1990-2005

$\mathrm{X}_{2}=$ Index for economic freedom for 2003

$$
\mathrm{CUCAB}=\mathrm{C}+\mathrm{B}_{1} \mathrm{X}_{1}+\mathrm{B}_{2} \mathrm{X}_{2}+\mathrm{u}
$$

Where:

$$
\begin{aligned}
\text { CUCAB }= & \text { Changes of Value of current account } \\
& \text { balances during 1997-2005 } \\
X_{1} & =\text { Index for political stability for 1990-2005 } \\
X_{2} & =\text { Index for economic freedom for 2003 }
\end{aligned}
$$

\section{RESULTS AND DISCUSSION}

Hypothesis of this study is that the variations of imbalances of balances of payment are due to the instability of political regimes among the countries. The countries which have more political stability are enjoying favorable balances in balance of payments. The balance of payment is dependent variables on political stability. I define balances such as Current account balance, Net foreign direct investment; international reserves and external value of currency are dependent variable on political stability.

Index for economic freedom takes value from 0-5. Low value means higher economic freedom. Higher values mean low economic freedom. Special Administrative Region (SAR) of Hong Kong (1.28) remains a model of economic freedom. It is in first rank. It is a free port with no barriers to trade; has simple procedures for starting enterprises, free entry of foreign capital and repatriation of earnings and transparency; and operates under the rule of law. Singapore (1.56) is in second rank. Democratic People's Republic of Korea (5.00) is undergoing some economic changes. It is in last rank.

In 2002, the government initiated tentative steps toward markets and entrepreneurship by creating semiprivate markets, shops and small business across the country. Part of these reforms included the phasing out of a decades-old food rationing and public distribution system and allowing prices and exchange rates to float. Nevertheless, the country remains firmly rooted in its communist and authoritarian system with its central command economy and deeper institutional reform is constrained by the degeneration of North Korea's industrial, transportation and energy infrastructure, which continues to be neglected for the sake of the government's military policy. Although reports indicate that there is greater economic activity in Pyongyang and other cities, economic deprivation seems to be worsening for most of the population.

According those factors, we can assume that the index for economic freedom is an indicator for economic factors determines the balance of payment. Theoretically, free market economy with economic freedom will lead to stabilization of economy in the long run. Generally both political and economical variables determine the stability of balance of payment. There may be some minor factors in determination of balances of balance of payment beyond those factors. But this study assumes other factors are constant now, we can rewrite the model as follow. 
Balances of payment $=\mathrm{f}$ (Index for political stability-1990-2005( $\left.\mathrm{X}_{1}\right)$ and Index for economic freedom-2003 $\left(\mathrm{X}_{2}\right)$.

\section{Political stability and international reserves:}

$$
\mathrm{IR}=\mathrm{C}+\mathrm{B}_{1} \mathrm{X}_{1}+\mathrm{B}_{2} \mathrm{X}_{2}+\mathrm{u}
$$

Where:

IR = Value of International reserves in 2005

$\mathrm{X}_{1}=$ Index for political stability for 1990-2005

$\mathrm{X}_{2}=$ Index for economic freedom for 2003

Bivariate and partial correlations between reserves and political and economic factors

$$
\begin{gathered}
\mathrm{r}_{\mathrm{yx} 1}^{2}=0.64 \\
\mathrm{r}^{2} \mathrm{yx}_{1} \cdot \mathrm{x}_{2}=0.82 \\
\mathrm{r}_{\mathrm{yx} 2}^{2}=0.146 \\
\mathrm{r}^{2} \mathrm{yx}_{2} \cdot \mathrm{x}_{1}=0.68
\end{gathered}
$$

William Kruskal ${ }^{[16]}$ gave an average proportion method to analyze the importance of variables.

$$
\text { Average proportion of } \begin{aligned}
\mathrm{X}_{1} & =\left(\mathrm{r}_{\mathrm{yx} 1}^{2}+\mathrm{r}_{\mathrm{yx} 1 . \mathrm{x} 2) / 2}^{2}\right. \\
& =(0.64+0.82) / 2 \\
& =0.73
\end{aligned}
$$

Average proportion of $\mathrm{X}_{2}=\left(\mathrm{r}_{\mathrm{yx} 2}^{2}+\mathrm{r}_{\mathrm{yx} 2 \mathrm{x} 1}^{2}\right) / 2$

$$
\begin{aligned}
& =(0.146+0.68) / 2 \\
& =0.413
\end{aligned}
$$

The result of average proportion method shows that variable of economic freedom (X2) has a weak effect on international reserves in selected countries.

\section{Regression results:}

$$
\begin{aligned}
& \text { IR }=-840.36+6.06 X_{1}+252.67 X_{2} \\
& \text { (371.68) (1.71) (210.32) } \\
& \begin{array}{lll}
\mathrm{t}-2.26 & 3.5 & 2.29
\end{array} \\
& \text { P-0.064 } 0.012 \quad 0.0619
\end{aligned}
$$

Where:

$\mathrm{R}^{2}=0.68$

$\mathrm{N}=9$

Table t-value $=2.447(5 \%)$

F statistics $=6.48$
When economic freedom increases, the international related economic activities increase. It leads to a favorable foreign reserve. Namely, economic freedom is expected to increase the foreign reserves through the stability of balance of payment. In our sample, two variables are significant in overall $F$ test. But, separately, the economic factors are not significant on international reserves. Its p-value is 0.061 and the factors of political stability are significant on reserves. Since the F-value is 6.48 , we can assume that there is no multicollinearty in these two dependent variables. The white heteroscedasticity test has a p-value 0.36 , which shows homoscedasticity.

One point increases in the index for political stability will lead to around 6 billion $\$$ increase of reserves. Further the factors which determine the political stability are more powerful for determination of reserves than economic factors. While a country is suffering political instability, it can not achieve a favorable foreign reserves even it has an attractive economic freedom to investors.

Jack Johnston ${ }^{[8]}$ explains a graphical method to show the relative importance of variables. Figure 1 shows that the relative importance of political stability factors and economic factors in determination of reserves by using Tinbergen diagram ${ }^{[8]}$. More fluctuation of independent variable means that the variable has more effect on dependent variables. On other hand less fluctuation indicates less effect of independent variables on dependent variables. It is clear; factors of political stability have more effect on

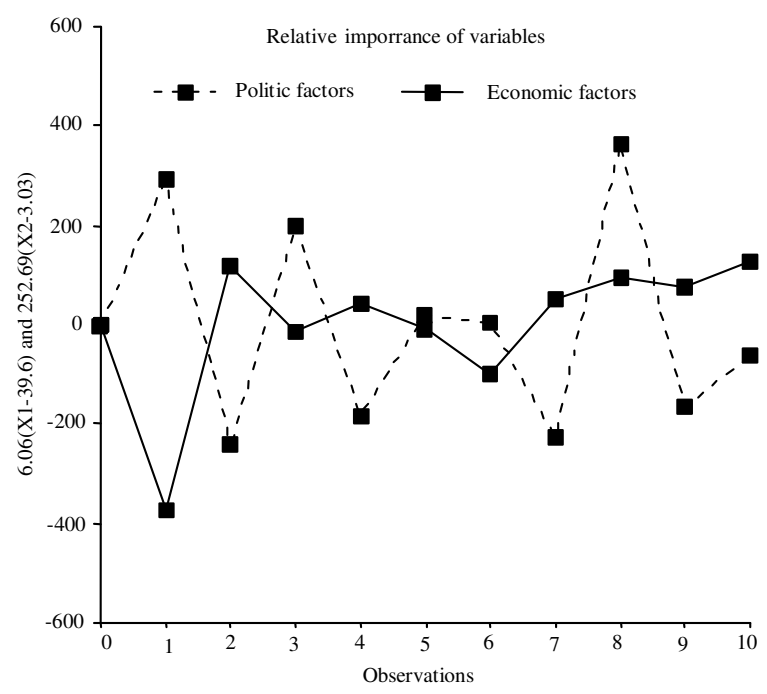

Fig. 1: Relative effect of political stability on International reserves 
in international reserve than factors for economic freedom. Foreign reserve can be maintained at a higher level while one country loose her external values of currency. Appreciation or depreciation of a currency also mainly depends on political factors than economic factors. The economies which had more political stability maintained their external values of currency at a stable position whereas the economies which had a weak political stability had lost their values of money on trading partners. Stability of external and internal values of currency can be explained as function of stability of Political regimes. Theoretically many literatures explain the stability of balance of payment by handling proper macro and micro economic policies. But the ground conditions of all policies highly depend on political stability. Economic policies are a like game in the world especially in international economics. One's victory in stability of balance of payment must be another's failure.

One country must take all policy actions in a long run visions. Therefore, the multi- party political system which often changes the leadership and policy makers lead to political instability hence economy becomes unstable. We turn to focus on the relationship between political stability and external value of currency.

Political stability and exchange rate stability: Bivariate and partial correlations between stability of currency and political and economic factors

$$
\begin{gathered}
r_{y 1 \times 1}^{2}=-0.714 \\
r_{y 1 \times 1 . x 2}^{2}=-0.690 \\
r_{y 1 \times 2}^{2}=0.154 \\
r_{y 1 \times 2 . x 1}^{2}=-0.124
\end{gathered}
$$

Average proportion of $X_{1}=\left(r^{2}{ }_{y 1 \times 1}+r^{2}{ }^{2} 1 \times 1 . x 2\right)$

$$
\begin{aligned}
& =(-0.714 \pm 0.69) / 2 \\
& =-0.72
\end{aligned}
$$

$$
\text { Average proportion of } \begin{aligned}
X_{2} & =\left(r^{2}{ }_{y 1 \times 2}+r^{2}{ }^{2} \times 2 . x 1\right) \\
& =(0.154 \pm 0.124) / 2 \\
& =0.03
\end{aligned}
$$

According to the relative importance analysis in correlation, the economic variable does not have any impact on exchange rate depreciation; even the exchange rate determination depends on government's policy, the more economic freedom an indicator of government's liberal exchange rate policy. Exchange rate stability mostly depends on the political stability. Average proportion of political stability on exchange rate stability is -0.72 . It is strongly shows that how a political stability determines the exchange rate stability in selected Asian countries. Regression analysis gives further evidence for this hypothesis.

$\begin{array}{llll}\mathrm{EXD}= & 116.29-0.868 \mathrm{IPS}-7.048 \mathrm{IEF} \\ \mathrm{Se} & (72.82) & (0.34) & (21.23) \\ \mathrm{t} & (1.59) & (-2.53) & (-0.33) \\ \mathrm{p} & 0.154 & 0.039 & 0.749\end{array}$

Where, $\mathrm{n}-10, \mathrm{R}^{2}=0.517$, Table $\mathrm{t}$-value $=2.36(5 \%)$, The white heteroscedasticity test has a p-value 0.52

$$
\mathrm{EXS}=92.67-0.812 \text { IPS }
$$

$\mathrm{t}(6.28)-(2.88)$, table $\mathrm{t}=2.30(5 \%), 2.8(10 \%)$

Economic freedom does not have significant with stability of exchange rate in comparing political stability. It does not affect the stability of currency. Political stability has considerable positive effect on stability of exchange rate. One point increases in index for political stability leads to 0.8 percent appreciation of currency against US\$ in Asia during the 1990 -2005. On other hand, one point decrease of index for political stability (Instability) leads to 0.868 percent of depreciation of currency. Stability of exchange rate is much closed link between stability of political regime. Figure 2 shows the relative importance of political stability to exchange rate stability.

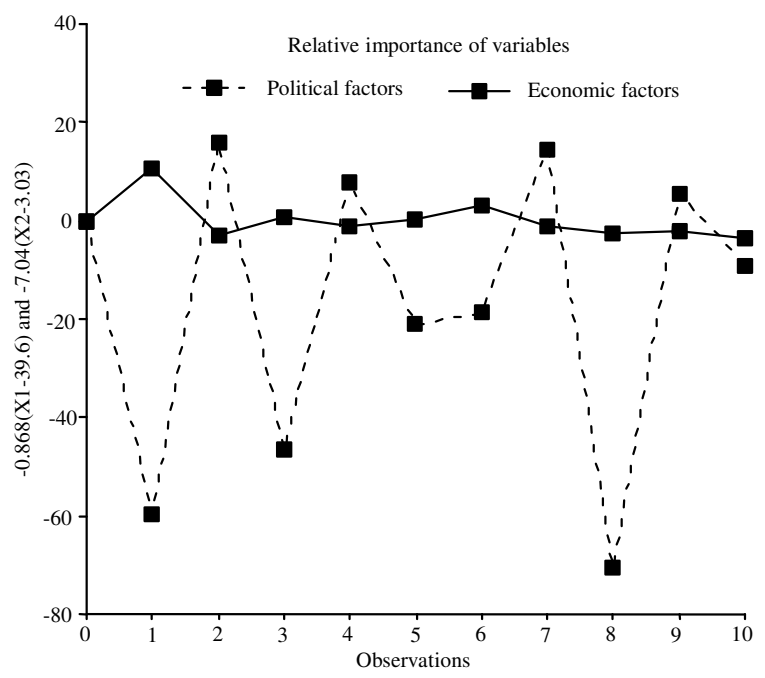

Fig. 2: Relative effects of political stability and economic freedom on exchange rate stability 
Political stability and net Foreign Direct Investment (FDI): Economic factor do not have any considerable effect on stability of currency. But factors for political stability have a strong influence on stability of exchange rate. We can see it through the William Kruskal's approach.

Bivariate and partial correlations between FDI and political and economic variables

$$
\begin{aligned}
& r_{y 2 \times 1}^{2}=0.705 \\
& r_{y 2 \times 1 . x 2}^{2}=0.84 \\
& r_{y 2 \times 2}^{2}=0.056 \\
& r_{y 2 \times 2 \times 1}^{2}=0.65
\end{aligned}
$$

$$
\text { Average proportion of } \begin{aligned}
X_{1} & =\left(r^{2}{ }^{2} \times 1+r^{2} y 2 \times 1 . x 2\right) / 2 \\
& =(0.705+0.84) / 2 \\
& =0.75
\end{aligned}
$$

$$
\text { Average proportion of } \begin{aligned}
\mathrm{X}_{2} & =\left(\mathrm{r}_{\mathrm{y} 2 \mathrm{x} 2}^{2}+\mathrm{r}_{\mathrm{y} 2 \mathrm{2} 2 \mathrm{x} 1 \mathrm{x}) / 2}\right. \\
& =(0.056+0.65) / 2 \\
& =0.35
\end{aligned}
$$

$$
\begin{aligned}
& \text { FDI }=-44+0.3578 \mathrm{X}_{1}+12.18 \mathrm{X}_{2} \\
& \text { Se (18.19) (0.08) (5.3) } \\
& \mathrm{t} \quad(-2.42)(4.16) \quad(2.298) \\
& \begin{array}{llll}
\mathrm{p} & 0.045 & 0.0042 & 0.055
\end{array}
\end{aligned}
$$

Where, $F=8.73$. The white heteroscedasticity test has a p-value 0.109 .

In FDI case, both variables have significant. But in the variable of economic freedom, the sign is different from one expected. It mean higher economic freedom have less FDI. Since partial correlation between economic freedom and FDI is zero, we can say that economic freedom does not affect the FDI mostly. It true one country can't attract the FDI unless maintaining of political stability. Even one country has more economic freedom; it can't attract FDI without stability of political regime. Economic freedom relatively has less importance on FDI than political stability. China is first rank in attracting FDI in the world because of the political stability. Figure 3 shows the relative importance of political stability in attracting FDI. Changes of FDI also show the same result.

$\mathrm{FDI}=\mathrm{C}+\mathrm{B}_{1} \mathrm{IPS}+\mathrm{B}_{2} \mathrm{IEF}+\mathrm{u}$

Where:

FDI $=$ Net FDI in 2003
IPS = Index for political stability for 1990-2005

IEF = Index for economic freedom for 2003

FDI $=-55.4+0.421 \mathrm{IPS}+15.31 \mathrm{IEF}$

$\begin{array}{llll}\mathrm{T} & -2.23 & 3.61 & 2.12\end{array}$

$\begin{array}{llll}\mathrm{P} & 0.063 & 0.0086 & 0.071\end{array}$

Where, $F=6.60$. The white heteroscedasticity test has a p-value 0.172 .

Political stability has more effect on FDI also. It has more fluctuation than economic freedom in Fig. 3.

Current account balances and political stability: Bivariate and partial correlations between FDI and political and economic variables

$$
\begin{aligned}
& r_{y 3 \times 1}^{2}=0.701 \\
& r_{y 3 \times 1 . x 2}^{2}=0.84 \\
& r_{y 3 \times 2}^{2}=0.058 \\
& r_{y 3 \times 2 . x 1}^{2}=0.65
\end{aligned}
$$

$$
\text { Average proportion of } \begin{aligned}
X_{1} & =\left(r^{2}{ }^{2} \times 1 r^{2} r^{2} \times 1 . x 2\right) / 2 \\
& =(0.701+0.84) / 2 \\
& =0.74
\end{aligned}
$$

$$
\begin{aligned}
& \text { Average proportion of } \mathrm{X}_{2}=\left(\mathrm{r}_{\mathrm{y} 3 \mathrm{x} 2}^{2}+\mathrm{r}_{\mathrm{y} 3 \mathrm{x} 2 . \mathrm{x} 1}^{2}\right) / 2 \\
& =(0.058+0.65) / 2 \\
& =0.34
\end{aligned}
$$

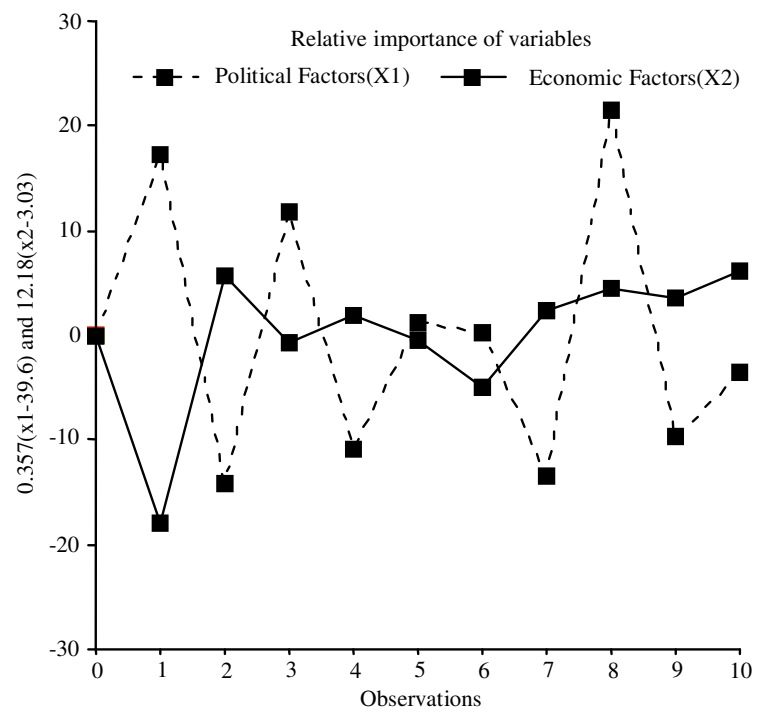

Fig. 3: Relative effects of political stability on FDI 


$\begin{array}{llll}\mathrm{CVCAB} & =-104.26+0.832 \text { IPS }+28.53 \text { IEF } \\ \mathrm{Se} & (42.82) & (0.20) & (12.4) \\ \mathrm{t} & (-2.43) & (4.12) & (2.28) \\ \mathrm{p} & -0.045 & 0.0045 & 0.056\end{array}$

Where, $\mathrm{N}-10, \mathrm{R}^{2}=0.709$, Table $\mathrm{t}$-value $=2.36(5 \%)$, $\mathrm{F}=8.98$. The white heteroscedasticity test has P-value 0.174 .

Political stability has significant on change of current account balance in during 1997-2005 and current account balance whereas economic freedom does not have significant effect on Current account balance. In changes case, one point increase in index of political stability improves the current account balance by US $\$ 0.832$ bi. In the year basis, one point increase in index of political stability improves the current account balance by US\$ 1.12 bi during in 2005. Relative importance of political stability on current Ac balance is shown in Fig. 4.

All cases in balances of balance of payment show that political stability is playing an importance role than economic factors measured by index of economic freedom. Now we have proved our hypothesis that political stability is key factor for determination of stability of balance of payment through the maintaining of stable balances. Theatrically, there is no evidence in incorporating of political stability in stability of balance of payment. This empirical study shows that relative importance of stability of political regime to stabilization of balance of payment.

\section{CONCLUSION}

Political stability is playing important role in determination of stability of balance of payment. Stable political regime with visionary leadership leads the nation to a higher level of favorable balance of payment. It makes a healthy economic environment to achieve stability of balance of payment. Pure theoretical macro economic policies can not make macro economic stability unless the country maintaining political stability.

This study has shown such as some macro economic variables related to balance of payment are healthy in selected Asian countries when the country maintains a solid political stability than economic freedom. Even though this study does not analyze deeply, the simple model has shown that the economies, which have more political stability, are enjoying a good balance of payment whereas the economies which have less political stability are facing balance of payment instability.

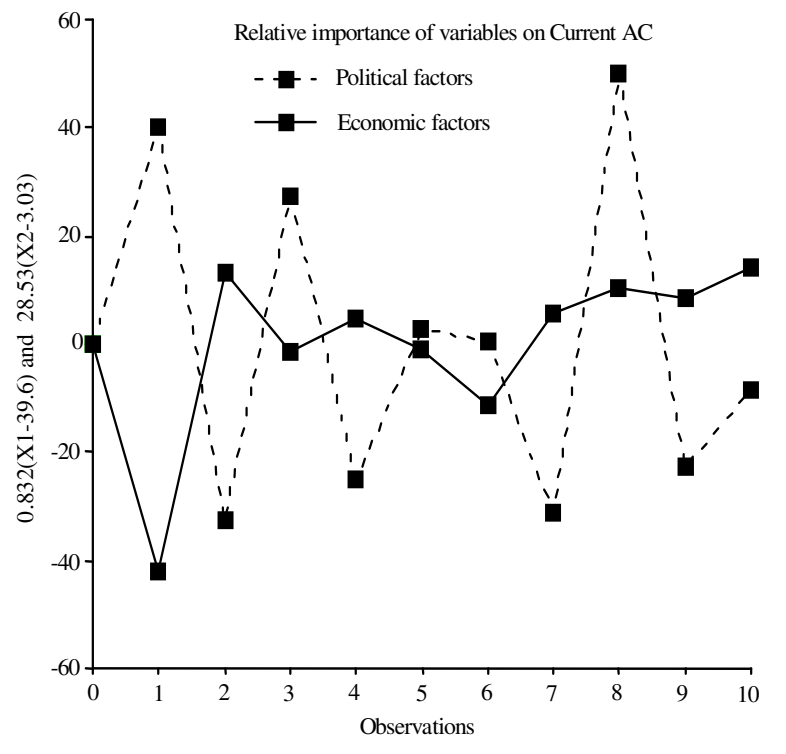

Fig. 4: Relative importance of political stability on current AC balance

This study further emphasize that political regime is playing an important role in determination of macro economic objectives specially balance of payment and currency stability. One party political system or authoritarian political regime with visionary leadership is more favorable to achieve stability of balance of payment as well as other macro economic objectives. The multi party political regime which often emphasis by western is not favorable to attain the macro economic stability specially balance of payment stability in developing countries.

Further economic policy and policy makers have to pay more attention on the political factors to achieve macro stability than economic factors. Singapore, China and Malaysia are good examples for these arguments. India, Sri Lanka, Philippines and Pakistan are good example for that how a political instability with multi party political system negatively affects and destroy the macro economic stability, especially stability of balance of payment and external value of currency.

\section{ACKNOWLEDGEMENT}

The author would be thankful to higher education commission of Pakistan (HEC) for financing me and Prof. R. Nanthakumaran, Dean, Vavuniya campus, FBM, University of Jaffna for the correction of first draft. 


\section{REFERENCES}

1. Alan C. Brennglass, 1983. The overseas private investment corporation, a study in political risk, Praeger publisher, USA.

2. Chow, Kit, Boey, Amina and Tyabji, 1980. External linkage and economic development: The Singapore experience, Economic Research Centre, monograph seris. 8, Chopmen publisher.

3. Chong-Yah and Peter. S. Lloyd, 1986. Singapore's Resources and Growth, Oxford University Press.

4. Gavin Peebles and Peter Wilson, 2002. Economic growth and development in Singapore past and future.

5. Heritage Foundation, 2006. Index for economic freedom, Available at http://www. heritage.org/ research/features/index/index.cfm.

6. Higgott, R. and A. Robinson, 1885. South East Asia-essays in political economy of structural Changes.

7. Hui jiong Wang, 2000. Integrated study of China's development and reforms Preliminary exploration at social system' foreign language presses Beijing, China.

8. Jack Johnson and Join Denardo, 1997. Econometric methods, 4th Edn. McGraw-Hill.

9. Joachim, A., 2002. Governance and economic development, new thinking in political economy. A Comparative Institutional approach, Edward Elgar press, Cheltenham, UK. Northampton, MA, USA.

10. Muhammad Younis, 2008. Political stability and economic growth in Asia. Am. J. Applied Sci., 5(3): 203-208.
11. Qiao Yu, 1990. Capital investment, international rate and economic growth in China. China Econ. Rev., 9 (1): 73-84.

12. Rummel Rudolf and A. Heenan David, 1978. How Multinationals analyze Political Risk. Havard Business Rev., pp: 67-76.

13. Saamsul Haque, S., 2004. Governance and Bureaucracy in Singapore, contemporary reform and implications. Int. Pol. Sci. Rev., 25 (2): 34-45.

14. Samantha, F. Ravich, 2000. Marketization and democracy: East Asian Experiences, centre for strategies and international studies. Washington, DC, Cambridge university press.

15. Steven M. Goldstein, 1991. Mini Dragons, Hong Kong, Singapore, South Korea and Taiwan, Fragile economic miracles in the Pacific. Westview press, Boulder, Oxford.

16. William Kruskal, 1987. Relative importance by averaging over ordering. The Am. Statis., 41: 6-10.

17. World Bank, 1996. The East Asian miracles, economic growth and public policy, a world bank policy research report. Oxford University press.

18. Wu Yan Yu, 2000. Is China's economic growth sustainable? China Econ. Rev., 11(3): 278-296.

19. Yan Wang and Yudong Yao, 2001. Source of china's economic growth, Incorporating human capital accumulation 1952-1999. Economic policy and poverty reduction division, World Bank Institute, World Bank. 